\title{
Tomato (Solanum lycopersicum L.) response to fertilizer nitrogen and compost ${ }^{1,2}$
}

\author{
David Sotomayor-Ramírez ${ }^{3}$,Elvin Román-Paoli ${ }^{3}$, \\ Luis E. Rivera ${ }^{3}$, Yuncong Li $i^{4}$ and Peter J. Stoffella ${ }^{5}$
}

J. Agric. Univ. P.R. 94(1-2):79-103 (2010)

\begin{abstract}
The effects of municipal biosolid yard-waste compost and fertilizer $\mathbf{N}$ applications on tomato (Solanum /ycopersicum L.) growth, yield and fruit quality were evaluated in Lajas (Typic Haplusterts) and Juana Díaz (Cumulic Haplustolls) (Fortuna Substation), Puerto Rico, for three years. In Fortuna, an initial application of compost at 50 t/ha significantly improved yields over those in unamended soil, yet a second application of compost the following year at 50 and $100 \mathrm{t} / \mathrm{ha}$, reduced yields. No residual effect of compost on tomato yields was detected the third year. In Fortuna, levels of $\mathbf{N}$ fertilization did not significantly affect tomato yields, growth or quality, except in the third year, when tomato yields were significantly higher in soils fertilized with $75 \mathbf{~ k g ~ N /}$ ha than yields from unfertilized soil. At Lajas, there was a significant crop response to fertilizer $\mathbf{N}$ in one of the two site years, when crop response to initial fertilizer $\mathbf{N}$ application was evaluated. Compost addition in Lajas did not improve yields or plant agronomic components for the first year of cropping tomato. The use of the SPAD chlorophyll meter may be a useful $\mathrm{N}$ diagnostic tool for tomato grown under drip irrigation and polyethylene mulch. In general, maximum SPAD values coincided with maximum yields, depending on the hybrid or variety planted; treatment effects were adequately separated out. The economic optimum $\mathbf{N}$ rate was relatively insensitive to fertilizer and tomato price fluctuations in the range selected. The calculated optimum $\mathbf{N}$ rate to achieve $99 \%$ yield goals was $143 \mathrm{~kg} \mathrm{~N} / \mathrm{ha}$, at sites with initial N application in Lajas, and $165 \mathrm{~kg} \mathrm{~N} / \mathrm{ha}$, respectively, for second and third applications of $\mathbf{N}$ in Fortuna, with maximum yields near $\mathbf{5 4}$ tha.
\end{abstract}

Key words: tomato, nitrogen fertilization, biosolid compost, nutrient management

${ }^{1}$ Manuscript submitted to Editorial Board 13 May 2009.

${ }^{2}$ We acknowledge the assistance of Manuel Matos, former graduate student at UPRM, and the assistance of UPRM-AES field personnel from Lajas and Fortuna. Funding for this study was provided by a USDA-TSTAR (formerly CBAG) grant to D. SotomayorRamírez.

${ }^{3}$ University of Puerto Rico-Mayagüez, College of Agricultural Sciences, Department of Crops and Agroenvironmental Sciences, PO Box 9000, Mayagüez, PR 00680-9000; corresponding author (D. Sotomayor): E-mail: david.sotomayor@upr.edu.

${ }^{4}$ University of Florida, IFAS, Tropical Research and Education Center, 8905 S.W. 280th St. Homestead, FL 33031-3314.

5University of Florida, IFAS, Indian River Research and Education Center, 2199 South Rock Road, Fort Pierce, FL 34945. 


\section{RESUMEN}

Respuesta de tomate (Solanum /ycopersicum L.) a la fertilización con nitrógeno y aplicación de composta

Por tres años se evaluaron los efectos de composta producida a partir de residuos vegetales y biosólidos, y de nitrógeno inorgánico en el crecimiento, rendimiento y calidad de fruta de tomate en las Subestaciones de Lajas (Typic Haplusterts) y Juana Díaz (Cumulic Haplustolls) (Subestación de Fortuna), Puerto Rico. En Fortuna, la aplicación de 50 tha aumentó el rendimiento sobre suelo sin enmendar pero una segunda aplicación de 50 y $100 \mathrm{t} / \mathrm{ha}$ redujo los rendimientos. No hubo un efecto residual de la composta en el tercer año. Los niveles de fertilización no incrementaron significativamente los rendimientos excepto en el tercer año, cuando los mayores rendimientos se obtuvieron con la aplicación de $75 \mathrm{~kg} \mathrm{~N} / \mathrm{ha}$ en forma de fertilizante inorgánico. En Lajas, hubo respuesta a la fertilización inicial en uno de los dos sitios-años. La adición de composta no mejoró los rendimientos ni los componentes agronómicos del tomate. El uso del medidor de clorofila SPAD puede ser útil para la producción de tomate cultivado en bancos elevados, con plástico y riego por goteo porque los valores máximos de SPAD coincidieron con los mayores rendimientos obtenidos. La medida sirvió para evaluar el efecto de los tratamientos, aunque los resultados dependen de la variedad o híbrido utilizado. El nivel óptimo económico obtenido fue poco sensitivo a los precios de fertilizante y tomate seleccionado. El nivel óptimo de fertilización de $\mathrm{N}$ para obtener el $99 \%$ de rendimiento máximo fue $143 \mathrm{~kg} \mathrm{~N} / \mathrm{ha}$ en áreas que recibieron aplicaciones iniciales de $\mathrm{N}$ en Lajas, $y$ $165 \mathrm{~kg} \mathrm{~N} / \mathrm{ha}$ en áreas con más de un año bajo el cultivo de tomate en Fortuna, con rendimientos cerca de 54 t/ha.

Palabras clave: tomate, fertilización, nitrógeno, composta de biosólidos, manejo de nutrientes

\section{INTRODUCTION}

The mixtures of biodegradable yard waste and sewage sludge compost can be applied to soils under agricultural production as a soil amendment and nutrient source, and as an ingredient in container media (Rosen et al., 1993; Smith, 1994; Chaney, 1996; Ozores-Hampton, 2004). Agricultural quality biosolid yard-waste compost is a mixture of sewage sludge, yard trimmings, and other biodegradable materials; it is currently being produced commercially in many states and in Puerto Rico (Roe and Stoffella, 1995; Raviv, 2005). Soils under vegetable production on the southern semi-arid coast of Puerto Rico are continuously cultivated. Amendment to these soils can improve their physical and chemical properties by returning organic matter and other nutrients. Since tomato (Solanum lycopersicum L.) is a valuable vegetable crop that requires high $\mathrm{N}$ input, and since soil organic matter is a major source of $\mathrm{N}$ from its mineralization, $\mathrm{N}$ availability to crops may be increased by supplementing these soils with compost (Roe et al., 1994; Martínez et al., 1999; Hartz et al., 2000). Other benefits such as increased microbial diversity and activity, enhanced micronutrient availability, and improved water availability and soil structure may also occur as a result of adding compost (Roe et al., 1997) 
Studies have shown increased vegetable crop yields with the application of biosolid-derived compost material (Roe et al., 1997; Roe et al., 1998). Bracette (2003) amended a Vertisol with 21 and 50 t/ha of compost and fertilizer-N at $75 \mathrm{~kg} / \mathrm{ha}$ in a field experiment planted to pepper (Capsicum annuum var. Key Largo); no significant effects of compost on growth and yields were observed. Sotomayor-Ramírez et al. (2000) amended a Vertisol for tomato grown in pots with up to 2,000 t/ha and observed improved plant vigor and plant biomass at the highest compost levels without any negative effects on plant growth indicators. Martínez et al. (1999) amended a Mollisol and an Ultisol with compost and quantified improvements in the chemical and physical properties. Other work has shown negative effects of compost on vegetable growth possibly because of salinity or phytotoxicity (Roe, 1998; Straw et al., 1998). More work is needed in Puerto Rico and other tropical areas to determine the potential benefits of compost addition and nitrogen $(\mathrm{N})$ response by high-valued vegetable crops such as raised-bed tomato under polyethylene mulch with drip irrigation. To date, only two studies have reported on tomato response to fertilizer-N addition in Puerto Rico (Abrams et al., 1975; O'Hallorans et al., 1993), although much work has been reported in Florida and elsewhere (Hochmuth and Hanlon, 1995; Straw et al., 1998; Abdul-Baki et al., 1997; Roe et al., 1997). It is important to quantify optimum fertilizer $\mathrm{N}$ application rates for tomato production; it is also important to gather knowledge on how organic materials such as compost may be used to reduce rates of inorganic fertilizer without significant reductions in yield. The objectives of this study were to quantify the effects of inorganic fertilizer $\mathrm{N}$ and biosolid yard-waste compost combinations on tomato crop growth, leaf nutritional response, and fruit yield and quality.

\section{MATERIALS AND METHODS}

Site description and experimental overview: For two consecutive years field experiments were conducted to evaluate the effects of inorganic fertilizer $\mathrm{N}$ and compost addition on tomato (Solanum lycopersicum L.) (www.ars-grin.gov) crop growth, leaf nutritional response and fruit yield and quality during the winter-spring periods of 19992000 and 2000-2001 (years 1 and 2) at the Agricultural Experiment Station farms in Lajas and in Juana Díaz (Fortuna). During the winterspring periods of 2001-2002 (year 3), the effects of fertilizer $\mathrm{N}$ and compost addition on tomato response was evaluated at another field site in Lajas, and the residual effects of two years of compost addition were evaluated in Fortuna. The environmental conditions and the soils at both Lajas and Fortuna are representative of those used for vegetable 
crop production on the southern semi-arid coast of Puerto Rico, which are a Fraternidad clay (Fine, smectitic, isohyperthermic Typic Haplusterts) and San Antón loam (Fine-loamy, mixed superactive, isohyperthermic Cumulic Haplustolls), respectively. At Fortuna, the field had previously been planted to tomatoes (1996-1997), onion (1997-1998), and was fallow from 1998 to 1999 . At Lajas, the field used in 1999 and 2000 had previously been cropped to tomatoes (1997-1998) and soybeans (1998-1999); the field used in 2001-2002 had been under corn-fallow cropping cycles for at least two years. At both sites, soil preparation included chemical defoliation of weeds, disk plowing, and harrow disking prior to bed preparation. All fields remained fallow between crops, except at Fortuna, where a cover-crop, sorghum (Sorghum bicolor L. Moench), was grown during the summer months of 2001 (between year 2 and year 3 crop cycles).

The compost material was obtained from a plant producing biosolid yard-waste compost (in the Arecibo municipality) operated by a private company under the auspices of the Solid Waste Management Authority of Puerto Rico. The material consisted of a mixture of municipal sewage sludge and yard trimmings and other woody material. The compost was transported to each field site and maintained in a covered pile for 30 to 60 days prior to application to soil. In all instances, planting was delayed for at least three weeks after adding compost to soil. Compost was applied manually to each bed and incorporated to a depth of $5 \mathrm{~cm}$ in Lajas according to the compost bulk density and moisture content. The compost was not incorporated at Fortuna. Soil beds were $0.15 \mathrm{~m}$ high, $0.90 \mathrm{~m}$ wide, and $1.8 \mathrm{~m}$ apart for all years. After application of compost treatments in 1999 and 2000 at both locations, and at Lajas in 2001, drip irrigation lines were placed simultaneously with the gray polyethylene mulch.

The experimental design was a randomized complete block in splitplot arrangement replicated four times (only two replicates were used in Lajas for 1999-2000). Treatments consisted of five fertilizer $\mathrm{N}$ levels as the main plots and three compost levels $(0,50,100 \mathrm{t} / \mathrm{ha})$ as the subplots. In Lajas for 2001-2002, the main plots were four fertilizer $\mathrm{N} \mathrm{lev-}$ els and the sub-plots were two compost levels ( 0 and $100 \mathrm{t} / \mathrm{ha}$ ). We evaluated the residual effects of previous compost additions in the 20012002 experiment (year 3), when no compost was applied in Fortuna. Each main plot consisted of two 31.4-m-long beds, and sub-plots were $10 \mathrm{~m}$ in Fortuna for all three years and in Lajas during 1999-2000 and 2000-2001. In the 2001-2002 experiment at Lajas, each main plot was 15.2-m long, and subplots were 7.6-m long.

In $1999-2000$, the $\mathrm{N}$ treatments were $0,67,135,201,268 \mathrm{~kg} / \mathrm{ha}$. The $\mathrm{N}$ levels were split in four equal portions and applied by fertigation 
with urea ammonium nitrate (UAN, $29.5 \% \mathrm{~N}$ ) at six, 36, 65, and 87 days after planting (DAP) in Lajas; and 15, 44, 77, and 96 DAP in Fortuna. In 2000-2001, the $\mathrm{N}$ rates were $0,75,150,225$, and $300 \mathrm{~kg} / \mathrm{ha}$ for both locations. One-half of the $\mathrm{N}$ rate was applied pre-plant to each bed and partially incorporated prior to polyethylene mulch placement. The pre-plant $\mathrm{N}$ source was urea $(46 \% \mathrm{~N})$ at Fortuna and ammonium sulfate $(21 \% \mathrm{~N})$ at Lajas. The remainder of the $\mathrm{N}$ treatments were applied by fertigation as $\left(\mathrm{NH}_{4}\right)_{2} \mathrm{SO}_{4}$ at 28, 52, and $90 \mathrm{DAP}$ in Fortuna, and at 35, 56, and 91 DAP as urea in Lajas. In the 2001-2002 experiment at Fortuna, the same rates, source, and placement were repeated as in the 2000-2001 experiment with the fertigation dates being 35, 56, and 91 DAP. At Lajas in the 2000-2001, the $\mathrm{N}$ rates were $0,100,200$, and 300 $\mathrm{kg} / \mathrm{ha}$ with one-half of the $\mathrm{N}$ rates applied pre-plant to each bed and partially incorporated prior to polyethylene mulch placement. The preplant $\mathrm{N}$ source was $\left(\mathrm{NH}_{4}\right)_{2} \mathrm{SO}_{4}$; the remainder of the $\mathrm{N}$ was applied by fertigation as urea at 20,42 and 64 DAP.

Pest control and other management practices: At both locations for the three years, insects were controlled with applications of Lanate ${ }^{\circledR}$ (methomyl) ${ }^{6}$, Xentari ${ }^{\circledR}$ (Bacillus thuringiensis var. Bizawar), Thiodan ${ }^{\circledR}$ (endosulfan), and Vydate ${ }^{\circledR}$ (oxamyl). Diseases were controlled with Bravo 500® (chlorothanil), copper sulfate, Benlate ${ }^{\circledR}$ (benomyl), and Manzate ${ }^{\circledR}$ (mancozeb). All products were applied as specified by the manufacturer's recommended rates. In 1999-2000 at both locations, phosphorus (P) was split-applied in two $25-\mathrm{kg}_{2} \mathrm{O}_{5} /$ ha portions as monopotassium phosphate (MKP, 0-52-34). Potassium was applied as monopotassium phosphate and potassium chloride in three portions at a total rate of $100 \mathrm{~kg} \mathrm{~K}_{2} \mathrm{O} / \mathrm{ha}$. In Lajas 2000-2001, P was applied pre-plant as triple superphosphate (TSP, $46 \% \mathrm{P}_{2} \mathrm{O}_{5}$ ) at the rate of $50 \mathrm{~kg} \mathrm{P}_{2} \mathrm{O}_{5} / \mathrm{ha}$. Potassium was applied at a total rate of $100 \mathrm{~kg} \mathrm{~K} \mathrm{~K}_{2} \mathrm{O} / \mathrm{ha}$ with a pre-plant rate of $50 \mathrm{~kg} \mathrm{~K}_{2} \mathrm{O} / \mathrm{ha}$ as $\mathrm{KCl}$, and the remainder amount was split in three portions and applied as $\mathrm{K}_{2} \mathrm{SO}_{4}$ with the $\mathrm{N}$ treatments by fertigation. At Fortuna, $\mathrm{P}$ and $\mathrm{K}$ were applied at a total rate of $50 \mathrm{~kg} \mathrm{P}_{2} \mathrm{O}_{5}$ /ha and $100 \mathrm{~kg} \mathrm{~K} / \mathrm{O} / \mathrm{ha}$, respectively. Half of the $\mathrm{P}$ and $\mathrm{K}$ was applied pre-plant as TSP and $\mathrm{K}_{2} \mathrm{SO}_{4}$, respectively, and the remainder was applied by fertigation in two portions as phosphoric acid and $\mathrm{K}_{2} \mathrm{SO}_{4}$, respectively. Fertilization $\mathrm{P}$ and $\mathrm{K}$ regimes were similar in the 2001-2002 experiments for the two locations.

\footnotetext{
${ }^{6}$ Trade names in this publication are used only to provide specific information. Mention of a trade name does not constitute a warranty of equipment or materials by the Agricultural Experiment Station of the University of Puerto Rico, nor is this mention a statement of preference over other equipment or materials.
} 
Irrigation: For each site, daily precipitation was measured with a rain gauge and evaporation was estimated from a class $\mathrm{A}$ evaporation tank. Water was applied to supply $100 \%$ of estimated evapotranspiration for the crop as:

$$
\mathrm{ET}_{1}=\mathrm{ET}_{0} * \mathrm{~K}_{\mathrm{c}} * \mathrm{~K}_{\mathrm{p}}
$$

where, $\mathrm{ET}_{1}$ is the estimated water to be applied by drip irrigation; $\mathrm{ET}_{0}$ is the reference evapotranspiration; $K_{c}$ is the crop coefficient; and $K_{p}$ is the site coefficient. The mean $\mathrm{K}_{\mathrm{p}}$ was 0.66 and 0.63 at Lajas and Fortuna, respectively (Goyal, 1989). The $\mathrm{K}_{\mathrm{c}}$ varied from 0.58 to 1.06 throughout the growing season at both sites and was adjusted accordingly (Goyal, 1989). Irrigation was performed every two days except on weekends, with $\mathrm{ET}_{1}$ calculated based on the days prior to scheduled irrigation but after previous irrigation. Irrigation water quantity was adjusted on the basis of an efficiency rating of $90 \%$ for the drip irrigation system. The amount of water at Lajas was added on a volume basis by using a metering device, and at Fortuna on a time basis considering flow rate data from irrigation lines.

Crop establishment and agronomic measurement: Tomato seedlings were transplanted into the beds and staked. At both locations the cultivar Bonanza was used in 1999-2000, and the hybrid Asgrow EF-49 was used in 2000-2001. In 2001-2002, the cultivar Floradade was used in Fortuna, and the hybrid Asgrow EF-49 was used in Lajas. In 1999-2000 plants were spaced in single rows $0.61 \mathrm{~m}$ apart with a plant population equivalent to 8,966 plants per hectare. In 2000-2001 and 2001-2002, plants were spaced in single rows 0.46 $\mathrm{m}$ apart with a plant population equivalent to 11,955 plants per hectare.

The relative green color of the leaf immediately below the top flower cluster (indicator leaf) of plants was measured with a SPAD502 chlorophyll meter (Minolta Corp., Ramsey, NJ). SPAD readings were taken at 30 and 60 DAP in 1999-2000, at 35 DAP in 2000-2001, and at 30 DAP in 2001-2002 for all locations. Five measurements were obtained from the indicator leaf and were averaged in order to obtain one observation per plant. Final SPAD readings were computed from the mean of four randomly selected plants. Indicator leaf $\mathrm{N}$ samples were gathered at the same time as SPAD readings for $\mathrm{N}$ concentration on the same dates for 1999-2000 and 2000-2001. In 2001-2002, leaf N concentration was quantified only in Fortuna. Plant biomass (fresh and dry weights) was quantified at $60 \mathrm{DAP}$ and at the 
first harvest in 1999-2000, at 35 DAP (and at bi-weekly intervals thereafter) in Lajas, and at harvest for both locations in 2000-2001. Leaf area index (LAI) was quantified at 60 DAP in 1999-2000, and at 35 DAP (and at bi-weekly intervals thereafter) in 2000-2001 in Lajas. The LAI was not quantified in Fortuna in 2000-2001, nor in Lajas or Fortuna in 2001-2002. A LICOR $3100 \circledR$ (LI-Cor Inc., Lincoln, NE) leaf-area meter was used for leaf area measurement, which was converted to LAI on the basis of plant density. Two plants from each plot were randomly selected and separated into leaves, stems and fruits for biomass and LAI measurement. A subsample of fruits, leaves and stems was used for dry weight determination and was converted to an aerial basis from moisture and plant density data. Plant nutrient $(\mathrm{N}$, $\mathrm{P}, \mathrm{K}, \mathrm{Ca}, \mathrm{Mg}, \mathrm{Fe}, \mathrm{Mn}, \mathrm{Zn}, \mathrm{Cu}, \mathrm{B})$ concentrations were measured in indicator leaves in 1999-2000 and 2000-2001.

Tomato yields were obtained from harvested fruit at maturity. In 1999-2000, only fruit without visual damage or deformation was included for final weighing and counting, and in other years all fruit was harvested and separated into marketable (classified by size) and non-marketable (all others). A subsample (50 fruits) of the total harvest was graded into small, medium, large, and extra large by using USDA grading (USDA, 1991). At Fortuna during 2000-2001 and 20012002, the "large" classification included large and extra large fruit classification. Fruits from each classification were counted and weighed. After tomato harvest in summer 2000, the polyethylene mulch was removed and sorghum seeds were drilled at a rate of $100,000 / \mathrm{ha}$. At 125 days after seeding, the biomass was mowed, left on the soil surface for 30 days and incorporated into the soil prior to the following year's tomato cropping.

Soil, plant, and compost analysis: Soils (0- to 15-cm depth) were sampled in fall of 1999-2000 (prior to experiment initiation) from the four main plots, and in fall of 2000-2001, soils (10 subsamples obtained randomly from each plot) were sampled from selected treatments to 0 - to $15-\mathrm{cm}$ depth. Soils were sieved to pass a $2-\mathrm{mm}$ sieve and air-dried prior to analysis. Nitrogen $\left(\mathrm{NH}_{4}{ }^{+}-\mathrm{N}\right.$ and $\left.\mathrm{NO}_{3}{ }^{-}-\mathrm{N}\right)$ was extracted with $1 \mathrm{M} \mathrm{KCl} \mathrm{(1:4} \mathrm{soil:solution)} \mathrm{followed} \mathrm{by} \mathrm{analysis} \mathrm{us-}$ ing an autoanalyzer by the University of Florida soil testing laboratory. Further characterization for $\mathrm{pH}$, soil electrical conductivity, organic matter, TKN, P, extractable $\mathrm{K}, \mathrm{Ca}, \mathrm{Mg}, \mathrm{Fe}, \mathrm{Mn}$, and $\mathrm{Zn}$ was performed on samples obtained from the 0- to 15-cm depth. Extractable $\mathrm{P}$ was determined by the Olsen method (Olsen and Sommers, 1982). Total Kjeldahl nitrogen (TKN) was determined by Kjeldahl digestion (Bremner and Mulvaney, 1982). Organic matter content was determined by dichromate digestion (Nelson and Sommers, 1982). 
Soil electrical conductivity and $\mathrm{pH}$ were determined in a 1:2 soil:solution suspension using water and $0.01 \mathrm{M} \mathrm{CaCl}$, respectively. Extractable bases were analyzed by atomic absorption spectrometry on a $1 \mathrm{M}$ $\mathrm{NH}_{4} \mathrm{OAC}$ extraction (Thomas, 1982).

Plant vegetative material was air dried at $65^{\circ} \mathrm{C}$ for $48 \mathrm{~h}$. The material was ground with a stainless steel mill to pass through a 1-mm mesh screen. A portion $(0.5 \mathrm{~g})$ of material was digested by using a microwave digestion apparatus with $10 \mathrm{ml}$ of concentrated $\mathrm{HNO}_{3}$ and 2 $\mathrm{ml} \mathrm{H}_{2} \mathrm{O}_{2}$. Analysis of $\mathrm{P}, \mathrm{K}, \mathrm{Ca}, \mathrm{Mg}, \mathrm{S}, \mathrm{Fe}, \mathrm{Mn}, \mathrm{Zn}$, and $\mathrm{Cu}$ in the extracts was performed using an inductively coupled plasma spectrometer (ICP) by the University of Florida soil testing laboratory (Gainesville, FL). The total $\mathrm{N}$ content was determined by Kjeldahl digestion. Compost material ( $<4 \mathrm{~mm}$ ) was ground in a grinding mill. A portion $(0.5 \mathrm{~g})$ of material was digested by a microwave digestion apparatus with $10 \mathrm{ml}$ of concentrated $\mathrm{HNO}_{3}$ and $2 \mathrm{ml} \mathrm{H}_{2} \mathrm{O}_{2}$. Analysis of $\mathrm{P}, \mathrm{K}, \mathrm{Ca}$, $\mathrm{Mg}, \mathrm{S}, \mathrm{Fe}, \mathrm{Mn}, \mathrm{Zn}$, and $\mathrm{Cu}$ in the extracts was performed as for tissue analysis.

The experiment was analyzed as a split-plot in a randomized complete block design using SAS (SAS Institute, Cary, NC). The data for all locations and years were analyzed separately. When treatment effects were significant, means separation was performed by using Tukey's LSD test. Non-linear regression analysis between fertilizer $\mathrm{N}$ and crop yields was performed with Sigma Plot (Systat Software, Inc., San José, CA). The tomato yield data was grouped in two. One group included Lajas 1999-2000 (year 1), Lajas 2001-2002 (year 3) and Fortuna 1999-2000 (year 1), and corresponded to crop response to initial application. The second group included Lajas 2000-2001 (year 2), Fortuna 2000-2001 (year 2) and Fortuna 2001-2002 (year 3), and corresponded to crop response to second and third fertilizer $\mathrm{N}$ applications. Since no crop response to fertilizer-N was observed for Fortuna 19992000 (year 1) or Lajas 2000-2001 (year 2), these were not included in the analyses. The data were expressed in terms of relative yield (yield of each treatment relative to the highest yielding treatment) and in terms of absolute yields. A quadratic equation was fitted to the relationship between $\mathrm{N}$ level applied and relative yield or absolute yield values (Cerrato and Blackmer, 1990). The optimum $\mathrm{N}$ level applied $\left(\mathrm{N}_{\text {critical }}\right)$ was found by the solution of the non-linear equation at 95 and 99\% maximum yield, and for absolute yields by establishing the first derivative and setting the solution equal to zero. Predicted optimum economic rates of fertilization were calculated by equating the first derivatives of the yield response equations to selected fertilizer- $\mathrm{N}$ to tomato price ratios of 2000 to $2002(\$ 0.55 / \mathrm{kg} \mathrm{N}$ and $\$ 0.55 / \mathrm{kg}$ tomato), and to ratios ranging from 2 to 8. 
TABLE 1. Chemical properties of compost used during 1999-2002 experiments.

\begin{tabular}{|c|c|c|c|c|c|c|c|c|c|c|c|c|c|}
\hline Year & $\mathrm{pH}^{1}$ & $\mathrm{EC}^{2}$ & $\mathrm{C} / \mathrm{N}$ & $\mathrm{OC}^{3}$ & $\mathrm{~N}^{4}$ & $\mathrm{P}$ & $\mathrm{Ca}$ & $\mathrm{Mg}$ & $\mathrm{K}$ & $\mathrm{Fe}$ & $\mathrm{Mn}$ & $\mathrm{Zn}$ & $\mathrm{Cu}$ \\
\hline & \multicolumn{3}{|c|}{$\ldots \ldots \mathrm{dS} / \mathrm{m} \ldots \ldots$} & \multicolumn{2}{|c|}{$\ldots \ldots-\ldots$} & \multicolumn{4}{|c|}{ - } & \multicolumn{4}{|c|}{$\ldots \ldots-\ldots m g / k g \ldots \ldots$} \\
\hline $1999-2000$ & 7.65 & 10.3 & 9.9 & 10.2 & 1.03 & 15.7 & 94.84 & 3.20 & 1.48 & 43,678 & 412 & 1,202 & 680 \\
\hline $2000-2001$ & 7.29 & 11.6 & 10.5 & 18.67 & 1.79 & 14.6 & 105.1 & 3.19 & 1.63 & 46,878 & 431 & 1,156 & 629 \\
\hline $2001-2002^{5}$ & 7.24 & 6.6 & 8.72 & 17.17 & 1.97 & 14.7 & 91.2 & 2.99 & 1.75 & 38,690 & 306 & 808 & 469 \\
\hline
\end{tabular}

${ }^{1} \mathrm{pH}$ measured in 1:2 soil:0.01M $\mathrm{CaCl}_{2}$ suspension.

${ }^{2} \mathrm{EC}$ is electrical conductivity measured in 1:2 soil:water suspension.

${ }^{3} \mathrm{OC}$ is oxidizable organic carbon measured by Walkley Black digestion during 1999-2000; OC measured in the 2000-2001 and 2001-2002 samples were measured by automated combustion.

${ }^{4} \mathrm{~N}$ is total nitrogen as determined by using a Kjeldahl digestion.

${ }^{5} \mathrm{~Pb}, \mathrm{Cd}, \mathrm{Ni}, \mathrm{Ba}$, and Mo concentrations were $193,4.7,82.7,300$, and $3.3 \mathrm{mg} / \mathrm{kg}$, respectively, for the $2001-2002$ sample. 


\section{RESULTS AND DISCUSSION}

\section{Soil and compost characterization}

Total elemental concentrations of the compost were similar to those of compost from the same source as reported by Martínez et al. (1999), except for electrical conductivity, which was lower possibly because of the use of alternative coagulating polymers at the sewage treatment plant. The lower C:N ratio measured in 1999-2000 material is explained by the fact that the Walkley-Black procedure utilized for organic $\mathrm{C}$ determination measures only a portion of the total $\mathrm{C}$ in the material, whereas the organic $\mathrm{C}$ of the material used in 2000-2001 and 2001-2002 experiments was determined with automated combustion. Although chemical quality standards for compost are not available, the materials used in our studies are generally within acceptable guidelines for municipal solid waste composts used for horticultural crops (Rosen et al., 1993; Raviv, 2005). The narrow C:N ratio of the compost material should favor $\mathrm{N}$ mineralization with a subsequent availability for crop growth. Using an estimate of $\mathrm{N}$ availability of $15 \%$ for the first year (Eghball and Power, 1999), we estimated that approximately 150 $\mathrm{kg} \mathrm{N} / \mathrm{ha}$ could be potentially available for crop growth with the $100 \mathrm{t} / \mathrm{ha}$ application. Further laboratory work by our group (Sotomayor et al. 2003) showed that the $\mathrm{N}$ potentially mineralized in 10 weeks ranged from 30 to $86 \mathrm{~kg} \mathrm{~N} / \mathrm{ha}$ (or 3 to $9 \%$ of the $\mathrm{N}$ added) at compost rates of 50 and $100 \mathrm{t} / \mathrm{ha}$, respectively. Hartz et al. (2000) reported that $6 \%$ of the $\mathrm{N}$ in a manure-compost was mineralized in 24 weeks. We quantified that the $1 \mathrm{M} \mathrm{KCl}$ extractable inorganic $\mathrm{N}$ pool of the compost was $278 \mathrm{mg} \mathrm{N} /$ $\mathrm{kg}$ compost. According to data by Sotomayor-Ramírez et al. (2003), the $\mathrm{N}$ availability to soil from the inorganic $\mathrm{N}$ pool of the compost and that which is potentially mineralized in 10 weeks (under laboratory conditions) with applications of either 50 or $100 \mathrm{t} / \mathrm{ha}$ is estimated at 43 and $60 \mathrm{~kg} \mathrm{~N} / \mathrm{ha}$ in San Antón soil, respectively, and at 77 and $113 \mathrm{~kg} \mathrm{~N} / \mathrm{ha}$ in Fraternidad soil, respectively.

One year after adding compost and $\mathrm{N}$ fertilization, soil $\mathrm{pH}$ increased as a result of adding compost in Lajas, but not in Fortuna (Table 2). This finding may be due to the inherently higher soil $\mathrm{pH}$ and soil buffering capacity of the San Antón soil. At both locations, soil organic matter and total Kjeldahl $\mathrm{N}$ increased as a result of adding compost. Extractable $\mathrm{NO}_{3}-\mathrm{N}$ values were higher as a result of $\mathrm{N}$ fertilization at both locations. Olsen extractable $\mathrm{P}$ and $\mathrm{NH}_{4} \mathrm{OAc}$ extractable $\mathrm{Ca}$ increased as a result of compost addition at both locations. Extractable $\mathrm{Mg}, \mathrm{K}$, and Na were generally not influenced by compost addition or $\mathrm{N}$ fertilization. 
TABLE 2. Soil (O- to 15-cm depth) characterization prior to experiment initiation (Fall 1999) and one year after the addition of compost (C) and nitrogen (N) (Fall 2000) at Lajas and Fortuna. Each value during Fall 2000 is the mean of four replicates from each field. treatment.

\begin{tabular}{|c|c|c|c|c|c|c|c|c|c|c|}
\hline \multirow[b]{2}{*}{ Treatment } & $\mathrm{pH}^{1}$ & $\begin{array}{l}\text { Organic } \\
\text { matter }^{2}\end{array}$ & $\begin{array}{c}\text { Total } \\
\text { Kjeldahl N }\end{array}$ & $\mathrm{NH}_{4}{ }^{+}-\mathrm{N}^{3}$ & $\mathrm{NO}_{3}^{-}-\mathrm{N}^{3}$ & $\begin{array}{l}\text { Extractable } \\
\qquad \mathrm{P}^{4}\end{array}$ & $\mathrm{Ca}^{5}$ & $\mathrm{Mg}$ & K & $\mathrm{Na}$ \\
\hline & & $\%$ & \multicolumn{4}{|c|}{$\ldots \ldots-\ldots$ mg/kg $\ldots \ldots \ldots$} & \multicolumn{4}{|c|}{ 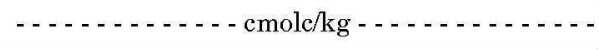 } \\
\hline & \multicolumn{10}{|c|}{ Lajas } \\
\hline $\begin{array}{l}\text { Fall } 1999 \\
\text { Fall } 2000\end{array}$ & 6.60 & 1.78 & 0.13 & 0.42 & 1.43 & 70.8 & 20.0 & 5.14 & 0.91 & 0.51 \\
\hline C1N1 & 6.65 & 1.82 & 0.11 & 23.3 & 7.5 & 46.8 & 31.83 & 11.66 & 0.71 & 0.35 \\
\hline C1N3 & 6.44 & 1.83 & 0.11 & 21.8 & 10.0 & 39.8 & 32.12 & 11.81 & 0.73 & 0.28 \\
\hline C1N5 & 6.35 & 1.86 & 0.11 & 26.5 & 21.3 & 52.0 & 32.04 & 11.05 & 0.86 & 0.31 \\
\hline C3N1 & 7.38 & 2.38 & 0.14 & 21.5 & 15.5 & 67.3 & 42.15 & 11.08 & 0.69 & 0.55 \\
\hline C3N3 & 7.36 & 2.39 & 0.13 & 19.0 & 16.3 & 76.3 & 42.18 & 10.92 & 0.44 & 0.41 \\
\hline \multirow[t]{2}{*}{ C3N5 } & 7.23 & 2.31 & 0.14 & 19.3 & 17.8 & 72.8 & 39.62 & 10.50 & 0.51 & 0.40 \\
\hline & \multicolumn{10}{|c|}{ Fortuna } \\
\hline $\begin{array}{l}\text { Fall } 1999 \\
\text { Fall } 2000\end{array}$ & 7.43 & 1.30 & 0.10 & 0.43 & 2.79 & 50.8 & 21.6 & 3.88 & 0.99 & 0.47 \\
\hline C1N1 & 7.65 & 1.62 & 0.10 & 5.0 & 8.8 & 56.5 & 27.86 & 4.06 & 0.50 & 0.53 \\
\hline C1N3 & 7.42 & 1.48 & 0.09 & 5.3 & 19.0 & 43.5 & 31.99 & 4.46 & 0.60 & 0.53 \\
\hline
\end{tabular}

${ }^{1} \mathrm{pH}$ measured in $1: 2$ soil: $0.01 \mathrm{M} \mathrm{CaCl}_{2}$ suspension

${ }^{2}$ Organic matter measured by dichromate oxidation

${ }^{3} \mathrm{NH}_{4}{ }^{+}-\mathrm{N}$ and $\mathrm{NO}_{3}-\mathrm{N}$ extracted with $1 \mathrm{M} \mathrm{KCl}$

${ }^{4}$ Extractable $\mathrm{P}$ performed with Olsen method

${ }^{5} \mathrm{Ca}, \mathrm{Mg}, \mathrm{K}, \mathrm{Na}$ extracted with $1 \mathrm{M}$ ammonium acetate $(\mathrm{pH}=7.0)$ 
TABLE 2. (Continued) Soil ( 0 - to 15-cm depth) characterization prior to experiment initiation (Fall 1999) and one year after the addition of compost (C) and nitrogen (N) (Fall 2000) at Lajas and Fortuna. Each value during Fall 2000 is the mean of four replicates from each field treatment.

\begin{tabular}{|c|c|c|c|c|c|c|c|c|c|c|}
\hline \multirow[b]{2}{*}{ Treatment } & \multirow[t]{2}{*}{$\mathrm{pH}^{1}$} & \multirow{2}{*}{$\begin{array}{c}\begin{array}{c}\text { Organic } \\
\text { matter }^{2}\end{array} \\
\%\end{array}$} & $\begin{array}{c}\text { Total } \\
\text { Kjeldahl N }\end{array}$ & $\mathrm{NH}_{4}{ }^{+}-\mathrm{N}^{3}$ & $\mathrm{NO}_{3}-\mathrm{N}^{3}$ & \multirow[t]{2}{*}{$\begin{array}{c}\text { Extractable } \\
\mathrm{P}^{4}\end{array}$} & \multirow[t]{2}{*}{$\mathrm{Ca}^{5}$} & $\mathrm{Mg}$ & K & \multirow[t]{2}{*}{$\mathrm{Na}$} \\
\hline & & & - . - . - . & $-m g$ & $g-\ldots$ & & & $--c$ & $g--$ & \\
\hline C1N5 & 7.16 & 1.46 & 0.09 & 6.8 & 14.0 & 46.5 & 24.28 & 4.34 & 0.50 & 0.50 \\
\hline C3N1 & 7.64 & 2.31 & 0.13 & 6.3 & 10.3 & 81.0 & 35.11 & 3.97 & 0.52 & 0.50 \\
\hline C3N3 & 7.66 & 2.75 & 0.15 & 7.0 & 10.0 & 85.8 & 36.03 & 3.64 & 0.72 & 0.39 \\
\hline C3N5 & 7.53 & 3.07 & 0.17 & 6.8 & 12.5 & 115.0 & 36.94 & 3.81 & 0.56 & 0.42 \\
\hline
\end{tabular}

${ }^{1} \mathrm{pH}$ measured in 1:2 soil:0.01M $\mathrm{CaCl}_{2}$ suspension

${ }^{2}$ Organic matter measured by dichromate oxidation

${ }^{3} \mathrm{NH}_{4}{ }^{+}-\mathrm{N}$ and $\mathrm{NO}_{3}-\mathrm{N}$ extracted with $1 \mathrm{M} \mathrm{KCl}$

${ }^{4}$ Extractable P performed with Olsen method

${ }^{5} \mathrm{Ca}, \mathrm{Mg}, \mathrm{K}, \mathrm{Na}$ extracted with $1 \mathrm{M}$ ammonium acetate $(\mathrm{pH}=7.0)$ 


\section{Tomato response to initial applications of nitrogen and compost}

Yields: At Fortuna in 1999-2000, there was no significant fertilizer $\mathrm{N} \times$ compost interaction nor fertilizer $\mathrm{N}$ effect on yields, number of fruits, or weight per fruit (Table 3). Mean yields were 74.1 t/ha. There was no significant compost effect with respect to the number of fruit or weight per fruit. The addition of compost ( 50 or $100 \mathrm{t} / \mathrm{ha}$ ) significantly increased yields, with no significant differences between the 50 and the $100 \mathrm{t} /$ ha compost treatments. At Fortuna $93 \%$ of the fruit was classified as large and x-large. At Lajas in 1999-2000, yields, number of fruits, and weight per fruit were unaffected by compost, fertilizer $\mathrm{N}$, and their interaction, although there was a tendency for yields and number of fruits to be highest with the 201-kg N/ha treatment. Mean yields were $51.3 \mathrm{t} / \mathrm{ha}$. Most of the fruits at Lajas were distributed about equally in the $x$-large, large, medium and small classifications, with values of 22 , 27,33 , and $18 \%$, respectively. There were no main effects or interactions in any of the size classifications.

At Lajas in the 2001-2002 experiment (year 3), the addition of $100 \mathrm{t} /$ ha of compost affected only the percentage distribution of tomatoes in the $\mathrm{x}$-large size classification, but did not influence total and marketable yields, total fruits, or total marketable fruits (Table 4). The interaction fertilizer $\mathrm{N} x$ compost was only marginally significant $(\mathrm{P}<0.09)$ for total marketable fruits, but was not considered important because the $\mathrm{N}$ main effect was highly significant. Fertilizer $\mathrm{N}$ at $100 \mathrm{~kg} \mathrm{~N} / \mathrm{ha}$ significantly increased yields over those in the $0 \mathrm{~kg}$ N/ha treatment with no significant differences among the highest $\mathrm{N}$ levels. There was no significant fertilizer $\mathrm{N}$ effect or fertilizer $\mathrm{N}$ x compost effect among the size classifications. Most of the fruits at Lajas were distributed in the large and extra large classifications. The proportion of small tomatoes tended to decrease and the proportion of x-large tomatoes tended to increase as a result of the addition of compost.

Plant biomass and nutrient status: No significant treatment effects (fertilizer $\mathrm{N}$, compost) nor interactions were detected in tomato leaf $\mathrm{N}$ or other nutrient concentrations in Lajas and Fortuna with an initial application (1999-2000) of fertilizer $\mathrm{N}$ and compost (Table 5). The values detected for each of the parameters in this experiment were at or above published sufficiency levels (Maynard and Hochmuth, 1997). SPAD readings at 30 DAP were significantly higher for the 135 $\mathrm{kg} \mathrm{N} / \mathrm{ha}$ fertilizer-N treatment, with maximum values of 57.9 and 58.7 in Fortuna and Lajas, respectively. SPAD readings at 60 DAP during 1999-2000 were not affected by fertilizer $\mathrm{N}$ and compost treatments in Fortuna, but were affected by fertilizer level in Lajas, with a maximum value of 58.4 with the $300 \mathrm{~kg} \mathrm{~N} / \mathrm{ha}$. Plant LAI at $60 \mathrm{DAP}$ was highest 
TABLE 3. Marketable tomato (var. Bonanza) yield response to initial fertilizer $N$ and compost applications in Fortuna and Lajas during 19992000 (year 1).

\begin{tabular}{|c|c|c|c|c|c|c|}
\hline Treatment & Yield & Number of fruits & Weight/fruit & Yield & Number of fruits & Weight/fruit \\
\hline & \multicolumn{3}{|c|}{$\ldots \ldots \ldots \ldots$ Fortuna $\ldots \ldots \ldots$} & \multicolumn{3}{|c|}{ 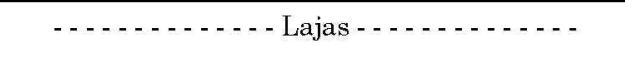 } \\
\hline & $\mathrm{kg} / \mathrm{ha}$ & \#/ha & $\mathrm{kg} /$ fruit & $\mathrm{kg} / \mathrm{ha}$ & \#/ha & $\mathrm{kg} /$ fruit \\
\hline \multicolumn{7}{|c|}{ Fertilizer $^{1}(\mathrm{~F})$} \\
\hline 0 & 74,496 & 386,263 & 0.198 & 43,491 & 262,237 & 0.168 \\
\hline 67 & 74,418 & 406,762 & 0.183 & 47,421 & 316,511 & 0.150 \\
\hline 135 & 72,121 & 382,389 & 0.189 & 51,352 & 642,530 & 0.150 \\
\hline 201 & 72,949 & 388,111 & 0.188 & 59,473 & 362,839 & 0.163 \\
\hline 268 & 76,498 & 408,472 & 0.188 & 54,398 & 341,561 & 0.160 \\
\hline F, $P=$ & 0.823 & 0.620 & 0.493 & 0.063 & 0.123 & 0.329 \\
\hline \multicolumn{7}{|c|}{ Compost $^{2}(\mathrm{C})$} \\
\hline 0 & $71,234 \mathrm{~b}^{3}$ & 382,473 & 0.186 & 50,118 & 317,088 & 0.160 \\
\hline 50 & $74,989 \mathrm{a}$ & 400,525 & 0.188 & 49,956 & 311,617 & 0.162 \\
\hline 100 & $76,234 \mathrm{a}$ & 400,201 & 0.191 & 53,608 & 346,702 & 0.152 \\
\hline $\mathrm{C}, P=$ & 0.029 & 0.232 & 0.275 & 0.718 & 0.338 & 0.350 \\
\hline $\mathrm{F} \times \mathrm{C}, P=$ & 0.516 & 0.473 & 0.757 & 0.593 & 0.324 & 0.265 \\
\hline
\end{tabular}

\footnotetext{
${ }^{1}$ Fertilizer rate expressed as $\mathrm{kg} \mathrm{N} / \mathrm{ha}$
}

${ }^{2}$ Compost level expressed as t/ha

${ }^{3}$ Within a column, means followed by different letters are significantly different $(\mathrm{P} \leq 0.05)$ according to Tukey's Least Significant Difference test. $P$ is the probability of the $F$ value in the analysis of variance. 
TABLE 4. Tomato (hybrid ' $E F-49$ ') response to initial fertilizer $N$ and compost applications in Lajas 2001-2002 (year 3).

\begin{tabular}{|c|c|c|c|c|c|c|c|c|}
\hline Treatment & Total yield & $\begin{array}{c}\text { Total } \\
\text { marketable yield }\end{array}$ & Total fruits & $\begin{array}{l}\text { Total } \\
\text { marketable fruits }\end{array}$ & Small & Medium & Large & X-large \\
\hline & \multirow{2}{*}{\multicolumn{2}{|c|}{ 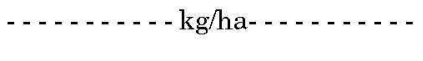 }} & \multicolumn{2}{|c|}{$\ldots \ldots \ldots$ \#/ha $\ldots \ldots \ldots$} & \multicolumn{4}{|c|}{$\ldots \ldots$ Size classification $\%$. $\ldots \ldots$} \\
\hline \multicolumn{7}{|c|}{ ( } & & \\
\hline 0 & $38,259 b^{3}$ & $31,552 \mathrm{~b}$ & $151,261 \mathrm{~b}$ & $121,224 \mathrm{c}$ & 6.6 & 23.4 & 32.0 & 38.0 \\
\hline 100 & 54,811 a & $47,970 \mathrm{a}$ & $198,513 \mathrm{ab}$ & $164,441 \mathrm{ab}$ & 8.2 & 19.3 & 29.7 & 42.8 \\
\hline 200 & 55,618 a & $48,813 \mathrm{a}$ & 209,003 a & 174,483 a & 8.5 & 21.4 & 30.1 & 40.1 \\
\hline 300 & $48,866 \mathrm{a}$ & $42,088 \mathrm{a}$ & $163,365 \mathrm{ab}$ & $137,363 \mathrm{cb}$ & 11.4 & 18.4 & 32.4 & 37.9 \\
\hline $\mathrm{F}, P=$ & 0.017 & 0.004 & 0.070 & 0.029 & 0.269 & 0.591 & 0.754 & 0.550 \\
\hline \multicolumn{9}{|l|}{ Compost $^{2}(\mathrm{C})$} \\
\hline 0 & 48,669 & 42,949 & 173,407 & 144,984 & 8.5 & 22.9 a & 30.6 & $37.3 \mathrm{~b}$ \\
\hline 100 & 50,108 & 42,263 & 187,664 & 153,771 & 8.8 & $18.3 \mathrm{~b}$ & 31.6 & $41.6 \mathrm{a}$ \\
\hline $\mathrm{C}, P=$ & 0.645 & 0.8057 & 0.2646 & 0.372 & 0.858 & 0.0234 & 0.676 & 0.033 \\
\hline $\mathrm{F} \times \mathrm{C}, P=$ & 0.779 & 0.7244 & 0.167 & 0.0911 & 0.179 & 0.944 & 0.809 & 0.256 \\
\hline
\end{tabular}

${ }^{1}$ Fertilizer rate expressed as $\mathrm{kg} \mathrm{N} / \mathrm{ha}$

${ }^{2}$ Compost level expressed as tha

${ }^{3}$ Within a column, means followed by different letters are significantly different $(\mathrm{P} \leq 0.05)$ according to Tukey's Least Significant Difference test. $P$ is the probability of the $F$ value in the analysis of variance. 
TABLE 5. Elemental analyses of indicator leaves as affected by an initial application of $N$ and compost in 1999-2000 experiment (year 1). No significant treatment effects (fertilizer $N$, compost nor interactions) were detected in any of the parameters measured.

\begin{tabular}{|c|c|c|c|c|c|c|c|c|c|c|}
\hline Location & $\mathrm{N}$ & $\mathrm{P}$ & $\mathrm{K}$ & $\mathrm{Ca}$ & $\mathrm{Mg}$ & $\mathrm{Fe}$ & $\mathrm{Mn}$ & $\mathrm{Zn}$ & $\mathrm{Cu}$ & $\mathrm{B}$ \\
\hline & \multicolumn{5}{|c|}{ - } & \multicolumn{5}{|c|}{$\ldots \ldots$. . . . mg/kg . . . . . . } \\
\hline Laj & 4.17 & 0.372 & 3.83 & 4.4 & 1.10 & 34 & 64 & 81 & 25 & 28 \\
\hline Fortuna & 4.92 & 0.375 & 4.81 & 3.97 & 0.699 & 31 & 100 & 40 & 27 & 43 \\
\hline
\end{tabular}

with the $225 \mathrm{~kg} \mathrm{~N} / \mathrm{ha}$ level (1.97) at Fortuna, and with the $300-\mathrm{kg} \mathrm{N} / \mathrm{ha}$ (1.66) level at Lajas. Plant biomass (dry matter, DM) at 30 DAP was not influenced by treatments, with means of $3,443 \mathrm{~kg}$ DM/ha in Fortuna and $2,514 \mathrm{~kg} \mathrm{DM} / \mathrm{ha}$ in Lajas. The SPAD readings at $30 \mathrm{DAP}$ during 2001-2002 in Lajas were highest (51.1) with the $100-\mathrm{kg}$ N/ha treatment without significant differences among higher $\mathrm{N}$ application levels. Leaf $\mathrm{N}$ concentrations were not measured at this time.

\section{Tomato response to a second application of fertilizer $N$ and com- post (2000-2001)}

Yield and size classification: At Fortuna in 2000-2001, total yields for the hybrid Asgrow EF-49 and its components were unaffected by fertilizer $\mathrm{N}$ (Table 6 ). Compost addition reduced total and marketable yields. Total fruits, total marketable fruits, and size classification were not affected by fertilizer- $\mathrm{N}$ or compost main effects. Overall, the percentage of medium and large plus $\mathrm{x}$-large tomatoes was 33.7 and $66.2 \%$, respectively.

At Lajas in the 2000-2001 experiment, fertilizer $\mathrm{N}$ and compost main effects did not influence total yields or total marketable yields (Table 7). There was a marginally significant $(\mathrm{P} \leq 0.1)$ fertilizer $\mathrm{N} \mathrm{x}$ compost interaction with respect to total yields. There was a significant $(\mathrm{P}<0.05)$ nitrogen $\mathrm{x}$ compost interaction with respect to total marketable yields and total fruits and marketable fruits, where compost addition at $50 \mathrm{t} / \mathrm{ha}$ with $0 \mathrm{~kg}$ N/ha increased yields over yields when not adding compost. Tomato size classifications were not influenced by fertilizer $\mathrm{N}$, compost or their interactions. Overall, the percentages of small, medium, large and $x$-large tomatoes were 20.0, 8.4, 22.3, and $49.3 \%$, respectively. We are unable to explain why there was a $57 \%$ yield reduction relative to the 1999-2000 crop in the same field.

Biomass, leaf area, leaf $N$, and chlorophyll status: Plant biomass and LAI were not gathered in Fortuna for year 2 (2000-2001). At 35 $\mathrm{DAP}$, there was a significant $\mathrm{N} \times$ compost interaction on leaf $\mathrm{N}$ concen- 
TABLE 6. Tomato (hybrid EF-49) response to a second application of $N$ and compost applications in Fortuna 2000-2001 (year 2).

\begin{tabular}{|c|c|c|c|c|c|c|}
\hline Treatment & Total yield & $\begin{array}{c}\text { Total } \\
\text { marketable yield }\end{array}$ & Total fruits & $\begin{array}{l}\text { Total } \\
\text { marketable fruits }\end{array}$ & Medium & Large and X-large \\
\hline & $\mathrm{kg} / \mathrm{ha}$ & $\mathrm{kg} / \mathrm{ha}$ & $\# /$ ha & \#/ha & - - - - - Size & ification $\%^{3}-\ldots$ \\
\hline \multicolumn{7}{|c|}{ Fertilizer $^{1}(\mathrm{~F})$} \\
\hline 0 & 49,186 & 48,139 & 201,183 & 195,225 & 34.0 & 66.0 \\
\hline 75 & 50,722 & 49,002 & 200,430 & 191,300 & 36.6 & 63.4 \\
\hline 150 & 53,184 & 50,987 & 198,487 & 187,822 & 30.7 & 69.3 \\
\hline 225 & 58,951 & 56,467 & 216,080 & 204,672 & 32.7 & 67.5 \\
\hline 300 & 56,183 & 53,751 & 215,197 & 206,236 & 35.0 & 65.0 \\
\hline $\mathrm{F}, P=$ & 0.283 & 0.438 & 0.905 & 0.806 & 0.589 & 0.589 \\
\hline \multicolumn{7}{|c|}{$\mathrm{Compost}^{2}(\mathrm{C})$} \\
\hline 0 & $58,189 \mathrm{a}^{4}$ & $56,138 \mathrm{~b}$ & 207,400 & 198,650 & 30.7 & 69.3 \\
\hline 50 & $52,260 \mathrm{~b}$ & $48,228 \mathrm{a}$ & 200,019 & 190,043 & 35.9 & 64.1 \\
\hline 100 & $50,487 \mathrm{~b}$ & $50,463 \mathrm{a}$ & 211,409 & 202,460 & 34.8 & 65.3 \\
\hline $\mathrm{C}, P=$ & 0.007 & 0.002 & 0.251 & 0.165 & 0.193 & 0.193 \\
\hline $\mathrm{F} \times \mathrm{C}, P=$ & 0.192 & 0.229 & 0.041 & 0.022 & 0.965 & 0.965 \\
\hline
\end{tabular}

${ }^{1}$ Fertilizer rate expressed as $\mathrm{kg} \mathrm{N} / \mathrm{ha}$

${ }^{2}$ Compost level expressed as tha

${ }^{3}$ Tomato in small size classification was not collected.

${ }^{4}$ Within a column, means followed by different letters are significantly different $(P \leq 0.05)$ according to Tukey's Least Significant Difference test. $\mathrm{P}$ is the probability of the $\mathrm{F}$ value in the analysis of variance. 
TABLE 7. Tomato (hybrid EF-49) size classification and yield response to a second application of fertilizer $N$ and compost applications in Lajas 2000-2001 (year 2).

\begin{tabular}{|c|c|c|c|c|c|c|c|c|}
\hline Treatment & Total yield & $\begin{array}{c}\text { Total } \\
\text { marketable yield }\end{array}$ & Total fruits & $\begin{array}{c}\text { Total } \\
\text { marketable fruits }\end{array}$ & Small & Medium & Large & X-large \\
\hline & $\mathrm{kg} / \mathrm{ha}$ & $\mathrm{kg} / \mathrm{ha}$ & \#/ha & \#/ha & \multicolumn{4}{|c|}{ 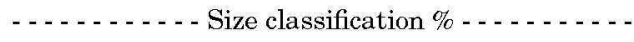 } \\
\hline \multicolumn{9}{|c|}{ Fertilizer $^{1}(\mathrm{~F})$} \\
\hline 0 & 28,767 & 23,395 & $146,713 \mathrm{ab}^{3}$ & 114,552 & 17.2 & 10.5 & 22.8 & 49.6 \\
\hline 75 & 31,591 & 25,012 & $160,855 \mathrm{a}$ & 125,777 & 27.1 & 7.9 & 22.1 & 42.9 \\
\hline 150 & 27,355 & 22,155 & 138,412 abc & 109,413 & 15.6 & 9.5 & 24.0 & 57.0 \\
\hline 225 & 24,256 & 19,912 & $118,529 \mathrm{c}$ & 960,051 & 20.3 & 7.5 & 23.9 & 48.3 \\
\hline 300 & 26,370 & 22,151 & $130,401 \mathrm{bc}$ & 108,539 & 19.8 & 6.6 & 19.0 & 54.6 \\
\hline $\mathrm{F}, P=$ & 0.134 & 0.438 & 0.0344 & 0.189 & 0.341 & 0.679 & 0.505 & 0.173 \\
\hline \multicolumn{9}{|c|}{ Compost $^{2}(\mathrm{C})$} \\
\hline 0 & 28,533 & 22,407 & 144,458 & 112,038 & 21.4 & 9.6 & 24.5 & 44.5 \\
\hline 50 & 27,703 & 22,426 & 137,382 & 110,179 & 19.9 & 7.9 & 20.9 & 51.3 \\
\hline 100 & 26,768 & 22,142 & 135,105 & 110,382 & 18.7 & 7.7 & 21.6 & 52.0 \\
\hline $\mathrm{C}, P=$ & 0.487 & 0.973 & 0.437 & 0.957 & 0.611 & 0.304 & 0.127 & 0.013 \\
\hline $\mathrm{F} \times \mathrm{C}, P=$ & 0.070 & 0.030 & 0.0455 & 0.0196 & 0.309 & 0.547 & 0.431 & 0.243 \\
\hline
\end{tabular}

${ }^{1}$ Fertilizer rate expressed as kg N/ha.

${ }^{2}$ Compost level expressed as t/ha.

${ }^{3}$ Within a column, means followed by different letters are significantly different $(\mathrm{P} \leq 0.05)$ according to Tukey's Least Significant Difference test. $\mathrm{P}$ is the probability of the $\mathrm{F}$ value in the analysis of variance 
tration. At $0 \mathrm{~kg} \mathrm{~N} / \mathrm{ha}$, the addition of compost at $50 \mathrm{t} / \mathrm{ha}$ significantly increased leaf $\mathrm{N}$ to $4.94 \%$ over that when not adding compost or compost at $100 \mathrm{t} /$ ha with a mean value of $4.43 \%$ in all of the other $\mathrm{N} \mathrm{x}$ compost treatments. In non-amended plots, fertilizer $\mathrm{N}$ at $300 \mathrm{~kg} \mathrm{~N} / \mathrm{ha}$ possibly $(\mathrm{P}<0.1)$ increased leaf $\mathrm{N}$ concentration $(4.84 \%)$ over that of the other $\mathrm{N}$ levels (mean of $4.26 \%$ ), but these values were not related to yields. Maximum SPAD readings were 49.0 with the $150 \mathrm{~kg}$ N/ha treatment.

At 35 DAP in Lajas for year 2 (2000-2001), plant biomass, LAI and leaf $\mathrm{N}$ concentration were not affected by treatments nor their interaction, with mean values of $781 \mathrm{~kg} / \mathrm{ha}, 0.237$, and $4.22 \%$, respectively. Leaf SPAD readings at 35 DAP reached highest values of 50.1 at $150 \mathrm{~kg}$ $\mathrm{N} / \mathrm{ha}$. AT $60 \mathrm{DAP}$, maximum SPAD readings were obtained at $100 \mathrm{~kg} \mathrm{~N} /$ ha with values of 51.1. At 60 DAP in Lajas, compost addition at 50 t/ha significantly increased plant biomass over that when not adding compost in plots without fertilizer N. Compost addition at 50 and $100 \mathrm{t} / \mathrm{ha}$ increased $(\mathrm{P}<0.01)$ plant LAI (mean of 0.778$)$ relative to that of unamended plots. There was a weak correlation $(\mathrm{P}<0.024 ; \mathrm{r}=0.40, \mathrm{n}=$ 35 ) between yields and leaf SPAD reading at 35 DAP. The SPAD meter may be useful for tomato grown under drip irrigation and polyethylene mulch because, in general, maximum values coincided with maximum yields, and the treatment effects were adequately separated out. Unfortunately, there was poor yield response to treatment effects and the lack of $(\mathrm{P}>0.05)$ or poor correlation with yields may be due to the large variability observed in yield data. Inter-annual variability in the optimum SPAD readings appears to be associated primarily with the tomato genetic material selected.

\section{Tomato response to a third application of nitrogen and residual effects of compost (Fortuna)}

Yield, size classification, and plant nutrient status: The fertilizer $\times$ compost interaction was significant only for total marketable fruits (Table 8). Total yields and total fruits were significantly influenced by fertilizer $\mathrm{N}$ applications but not by compost applications. The addition of $75 \mathrm{~kg}$ N/ha significantly increased total yields and total fruits over those of the control treatment, with no significant differences among $\mathrm{N}$ levels. Total marketable yields increased from 33,649 to $37,661 \mathrm{~kg} / \mathrm{ha}$ with the addition of compost at $50 \mathrm{t} / \mathrm{ha}$, whereas no fertilizer $\mathrm{N}$ effect was observed. Neither fertilizer $\mathrm{N}$ addition nor fertilizer $\mathrm{N} x$ compost interaction affected the fruit size distribution. The addition of $50 \mathrm{t} /$ ha significantly increased the number of $x$-large tomatoes over the number when compost was not added. The maximum response to fertilizer- $\mathrm{N}$ coincided with maximum SPAD values of 51.5 at 30 DAP. Maximum leaf $\mathrm{N}$ concentration was $4.25 \%$ at fertilizer $\mathrm{N}$ levels between 75 and $150 \mathrm{~kg} \mathrm{~N} / \mathrm{ha}$. 
TABLE 8. Tomato (var. Floradade) response to a third application of $N$ and residual BYW compost applications in Fortuna $2001-2002$ (year 3).

\begin{tabular}{|c|c|c|c|c|c|c|c|c|}
\hline Treatment & Total yield & $\begin{array}{c}\text { Total } \\
\text { marketable yield }\end{array}$ & Total fruits & $\begin{array}{c}\text { Total } \\
\text { marketable fruits }\end{array}$ & Small & Medium & Large & X-large \\
\hline & $\mathrm{kg} / \mathrm{ha}$ & $\mathrm{kg} / \mathrm{ha}$ & \#/ha & $\# /$ ha & $\ldots$ & - Size clas & ation $(\%)$ & $\ldots$ \\
\hline \multicolumn{9}{|c|}{ Fertilizer $^{1}(\mathrm{~F})$} \\
\hline 0 & $40,335 \mathrm{~b}^{3}$ & 32,104 & $268,943 \mathrm{~b}$ & $200,390 \mathrm{c}$ & 1.5 & 18.9 & 44.9 & 34.6 \\
\hline 75 & $48,123 \mathrm{a}$ & 34,182 & $323,673 \mathrm{a}$ & $212,419 \mathrm{cb}$ & 2.4 & 23.2 & 43.7 & 30.7 \\
\hline 150 & 48,162 a & 37,718 & $323,822 \mathrm{a}$ & 237,151 a & 1.3 & 21.6 & 43.1 & 34.0 \\
\hline 225 & 50,607 a & 37,894 & $341,808 \mathrm{a}$ & $236,478 \mathrm{ab}$ & 1.8 & 20.9 & 43.7 & 33.7 \\
\hline 300 & $50,158 \mathrm{a}$ & 36,128 & $332,738 \mathrm{a}$ & $215,035 \mathrm{abc}$ & 2.2 & 22.8 & 41.9 & 33.1 \\
\hline $\mathrm{F}, P=$ & 0.077 & 0.128 & 0.012 & 0.025 & 0.860 & 0.832 & 0.943 & 0.873 \\
\hline \multicolumn{9}{|c|}{$\mathrm{Compost}^{2}(\mathrm{C})$} \\
\hline 0 & 45,787 & 33,649 & 341,808 & $209,491 \mathrm{a}$ & 2.0 & 20.1 & 42.3 & 35.6 \\
\hline 50 & 49,145 & 37,661 & 332,738 & 227,871 a & 2.4 & 20.5 & 43.0 & 34.1 \\
\hline 100 & 46,859 & 35,506 & 335,438 & $223,522 \mathrm{ab}$ & 1.1 & 23.8 & 45.0 & 30.0 \\
\hline $\mathrm{C}, P=$ & 0.370 & 0.066 & 0.736 & 0.039 & 0.446 & 0.133 & 0.430 & 0.030 \\
\hline $\mathrm{F} \times \mathrm{C}, P=$ & 0.599 & 0.797 & 0.219 & 0.036 & 0.777 & 0.196 & 0.415 & 0.164 \\
\hline
\end{tabular}

${ }^{1}$ Fertilizer rate expressed as $\mathrm{kg} \mathrm{N} / \mathrm{ha}$

${ }^{2}$ Compost level expressed as tha

${ }^{3}$ Within a column, means followed by different letters are significantly different $(P \leq 0.05)$ according to Tukey's Least Significant Difference test. $\mathrm{P}$ is the probability of the $\mathrm{F}$ value in the analysis of variance. 

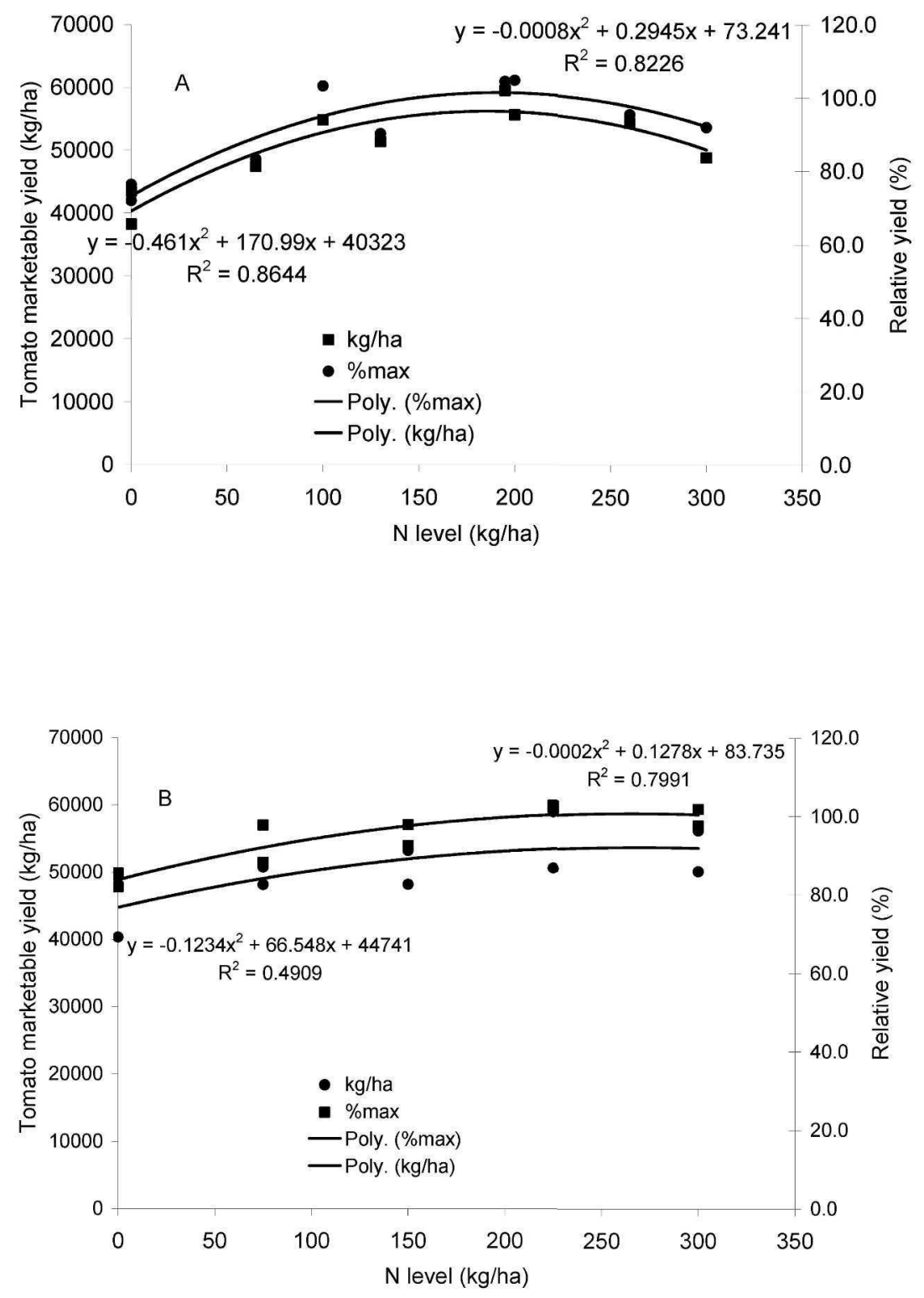

FIGURE 1. Yield response to $\mathrm{N}$ fertilization in (A) Lajas as influenced by an initial fertilizer $\mathrm{N}$ in two site-years, and in (B) Fortuna as influenced by a second and third $\mathrm{N}$ application in the same field. There was no crop response to a second fertilizer $\mathrm{N}$ application in Lajas nor to an initial fertilizer $\mathrm{N}$ application in Fortuna (data not shown). 


\section{Compost and nutrient recommendations}

Crop yield response to compost addition was observed in Fortuna in the first year of cropping; reduced yields were observed in year 2; no residual effects were observed in year 3 . Yield response to an initial addition or residual effect of compost was not observed in Lajas; however, some of the yield components and plant agronomic parameters were positively influenced by compost addition, as had been observed by Sotomayor-Ramírez et al. (2000). The results of this field study demonstrate that the compost evaluated is unable to supply enough $\mathrm{N}$ in a 12week period to increase tomato yields over yields when not amending soil with or without fertilizer-N addition. Reported $\mathrm{N}$ mineralization rates from municipal solid waste composts are generally low but vary considerably, depending on the type of materials used in composting, $\mathrm{N}$ concentration, processing form, time of application, soil type added and environmental conditions (Straw et al., 1998; Hartz et al., 2000). Losses such as those occurring from ammonia volatilization after soil incorporation may be another factor causing the poor plant $\mathrm{N}$ availability (Hadas and Portnoy, 1994). A long-term compost addition program to increase soil $\mathrm{N}$ availability is not warranted when using soils, management and cropping practices similar to those in this study, given the apparent high $\mathrm{N}$ supplying capacity of the soils.

Some negative effects of municipal biosolid compost have been observed (Straw et al., 1998), although most studies have shown that vegetable yields are increased with combinations of fertilizer- $\mathrm{N}$ and compost applications as compared to yields with only fertilizer $\mathrm{N}$ or compost (Roe et al., 1997a; Valenzuela and Crosby, 1998; Roe et al., 1998). Of all the horticultural uses of compost, the greatest public concern occurs in crops used for direct human consumption such as tomatoes, primarily with heavy metal loading and pathogen transfer. Chaney (1996) showed that the addition of compost (at 10x the rates used in our study) would not increase the risk for heavy metal transfer to humans from garden foods. Potentially toxic compounds as well as pathogenic organisms are destroyed during adequately composting municipal solid wastes (Raviv, 2005). Perhaps the greatest benefit of the type of compost used in the study may be as a soil conditioner through increased organic matter leading to improved physical properties, higher CEC, and improved microbial diversity and microbial activity (Ozores-Hamptom, 2004).

Maximum yields when crop response was observed in Lajas and Fortuna were $56 \mathrm{t} / \mathrm{ha}$ and $54 \mathrm{t} / \mathrm{ha}$, respectively. Because farmers usually overestimate their yield goals, it is common to calculate optimum $\mathrm{N}$ rates to achieve 95 and $99 \%$ of maximum yields (Cerrato and Black- 
mer, 1990). The calculated optimum $\mathrm{N}$ rates to achieve 95 and $99 \%$ yield goals were 102 and $143 \mathrm{~kg} \mathrm{~N} / \mathrm{ha}$, respectively, with an initial N application in Lajas. Similarly, the calculated optimum $\mathrm{N}$ rates to achieve 95 and $99 \%$ yield goals were 110 and $165 \mathrm{~kg} \mathrm{~N} / \mathrm{ha}$, respectively, for second and third applications of $\mathrm{N}$ in Fortuna. The analysis can be used to improve previously suggested $\mathrm{N}$ application rates of up to $120 \mathrm{~kg} \mathrm{~N} / \mathrm{ha}$ for tomato, pepper and eggplant in soils dominated by 2:1 clays on the southern coast of Puerto Rico (Sotomayor-Ramírez and Macchiavelli, 2002). Our data demonstrate that it is profitable to increase $\mathrm{N}$ rates to values ranging from 143 to $165 \mathrm{~kg} \mathrm{~N} / \mathrm{ha}$ and still achieve $99 \%$ of maximum yields on sites with similar management. The economic optimum $\mathrm{N}$ rate varied by $3.8 \%$ in Lajas and $9.2 \%$ in Fortuna within a range of fertilizer-crop ratios of 2 to 8 , all of which demonstrates that the $\mathrm{N}$ recommendation is relatively insensitive to fertilizer and tomato price fluctuations in the range selected. Increasing fertilizer $\mathrm{N}$ rates beyond those recommended will not result in apparent financial loss. However, the cost of environmental degradation from the inefficient use of $\mathrm{N}$ is not included in the estimate. Nitrogen use efficiency has been shown to decrease with increasing $\mathrm{N}$ applied (Andersen et al., 1999), with resulting nonlinear increase of excess $\mathrm{N}$ in the soil profile at or beyond the economic N rates for many crops (Vanotti and Bundy, 1994). Given the lack of consistent crop response to compost addition, this practice is not warranted in similar Vertisols and Mollisols soils of the southern coast of Puerto Rico.

\section{LITERATURE CITED}

Abdul-Baki, A. A., J. R. Teasdale and R. F. Koreak, 1997. Nitrogen requirements of fresh market tomatoes on hairy vetch and black polyethylene mulch. HortScience 32:217221.

Abrams, R., L. Cruz-Pérez, R. Pietri-Oms and F. J. Julia, 1975. Effect of fertilizer N, P, K, $\mathrm{Ca}, \mathrm{Mg}$, and $\mathrm{Si}$ on tomato yield in an Oxisol. J. Agric. Univ. P.R. 59:26-34.

Andersen, P. C., F. M. Rhoads, S. M. Olson and K. D. Hill, 1999. Carbon and nitrogen budgets in spring and fall tomato crops. HortScience 34:648-652.

Bracette, J., 2003. Mineralización de nitrógeno en un Vertisol enmendado con composta. M.S. Thesis. Agronomy and Soils Department, Univ. of Puerto Rico. 64 pages.

Bremner, J. M. and C. S. Mulvaney, 1982. Nitrogen-total. p. 595-624. In: A. L. Page, R. H. Miller and D. R. Keeney (Eds.). Methods of soil analysis, Part 2, Chemical and microbiological properties. Second edition. ASA, SSSA, Madison, WI.

Cerrato, M. E. and A. M. Blackmer, 1990. Comparison of models for describing corn yield response to nitrogen fertilizer. Agron. J. 98:138-143.

Chaney, R. L., 1996. Plant nutrition and heavy metal aspects of compost use. HortScience 31:564-702.

Eghball, B. and J. F. Power, 1999. Composted and non-composted manure application to conventional and no-tillage systems: Corn yield and nitrogen uptake. Agron. J. 99:819-825. 
Goyal, M. R. (Ed.), 1989. Irrigation research and extension progress in Puerto Rico. Agricultural Experiment Station. University of Puerto Rico.

Hadas, A. and R. Portnoy, 1994. Nitrogen and carbon mineralization rates of composted manures incubated in soil. J. Environ. Qual. 23:1184-1189.

Hartz, T. K., J. P. Mitchell and C. Giannini, 2000. Nitrogen and carbon mineralization dynamics of manures and composts. HortScience 35:209-212.

Hochmuth, G. J. and E. A. Hanlon, 1995. Commereial vegetable crop nutrient requirements in Florida. Florida Coop. Extension Serv. Circ. SP 177.

Martínez, G. A., J. L. Guzmán, M. A. Vázquez, L. E. Rivera and A. González, 1999. Chemical and physical properties of two tropical soils treated with sewage sludge compost. J. Agric. Univ. P.R. 83:103-121.

Maynard, D. N. and G. J. Hochmuth, 1997. Knott's handbook for vegetable growers, Fourth Ed. John Wiley and Sons, Inc., NY.

Nelson, D. W. and L. E. Sommers, 1982. Total carbon, organic carbon, and organic matter. p. 549-579. In: A. L. Page, R. H. Miller and D. R. Keeney (Eds.). Methods of soil analysis, Part 2, Chemical and microbiological properties. Second edition. ASA, SSSA, Madison, WI.

O'Hallorans, J. M., M. A. Muñoz and O. Colberg, 1993. Effect of chicken manure on chemical properties of a Mollisol and tomato production. J.Agric. Univ. P.R. 77:181-191.

Olsen, S. R. and L. E. Sommers, 1982. Phosphorus. p. 403-430. In: A. L. Page, R. H. Miller and D. R. Keeney (Eds.). Methods of soil analysis, Part 2, Chemical and microbiological properties. Second edition. ASA, SSSA, Madison, WI.

Ozores-Hampton, M., 2004. Survey of compost use by South Florida vegetable growers. HortScience 39:745-897.

Raviv, M., 2005. Production of high-quality composts for horticultural purposes: A minireview. HortTechnology 15:52-57.

Roe, N. E., 1998. Compost utilization for vegetable and fruit crops. HortScience 33:934937.

Roe, N. E. and P. J. Stoffella. 1995. Biosolids-yard trimming composts increases bell pepper (Capsicum annuum L.) and cucumber (Cucumis sativus L.) yields. HortScience 30:195-914.

Roe, N. E., P. J. Stoffella and D. Graetz, 1997. Composts from various municipal solid waste feedstocks affect vegetable crops. II. Growth, yields and fruit quality. J. Amer. Soc. Hort. Sci. 122:433-437.

Roe, N. E., P. J. Stoffella and H. H. Bryan, 1994. Growth and yields of bell pepper and winter squash grown with organic and living mulches. J. Amer. Soc. Hort. Soc. 119:1193-1199.

Rosen, C. J., T. R. Halbach and B. R. Swanson, 1993. Horticultural uses of municipal solid waste composts. HortTechnology 3:167-173.

Smith, W. H., 1994. Recycling composted organic material in Florida. Univ. Florida, Fla. Coop. Ext. Ser. BP-2.

Sotomayor-Ramírez, D. and R. Macchiavelli, 2002. Interpretations of field fertility research on Solanaceae in Puerto Rico. J. Agric. Univ. P.R. 86:95-116.

Sotomayor-Ramírez, D., E. Román-Paoli and L. E. Rivera, 2000. Tomato (Lycopersicon esculentum Mill.) response to biosolid yard-waste compost. Proceedings Caribbean Food Crops Society 36:81-86.

Sotomayor-Ramírez, D., E. Román-Paoli and L. E. Rivera, 2003. Nitrogen availability in vegetable systems amended with biosolid yard-waste compost. Annual Progress Report of Research Projects. Agric. Experiment Station, Final Project Report.

Straw, R. A., R. A. Gilfillen, M. D. Mullen and C. A. Mullins, 1998. Yield of tomatoes as influenced by time of application of municipal biosolids. HortScience 33:583-768. 
Thomas, G. W., 1982. Exchangeable cations. p. 159-179. In: A. L. Page, R. H. Miller and D. R. Keeney (Eds.). Methods of soil analysis, Part 2, Chemical and microbiological properties. Second edition. ASA, SSSA, Madison, WI.

USDA, 1991. United States standards for grades of fresh tomatoes. USDA Agricultural Marketing Service, Fruit and Vegetable Division. Reprinted Jan. 1997.

Valenzuela, H. R. and C. Crosby, 1998. Effect of compost applications on the yield of several vegetables in long-term organic farming experiments conducted in the tropics. HortScience 33:443-558.

Vanotti, M. B. and L. G. Bundy, 1994. An alternative rationale for corn nitrogen fertilizer recommendations. J. Prod. Agric. 7:243-249. 
